\title{
Article
}

\section{Fragile finance: The revenue models of oppositional news outlets in repressive regimes}

\author{
Cook, Clare Elizabeth
}

Available at http://clok.uclan.ac.uk/12927/

Cook, Clare Elizabeth ORCID: 0000-0001-5063-6013 (2016) Fragile finance: The revenue models of oppositional news outlets in repressive regimes. The International Communication Gazette, 78 (6). pp. 514-535. ISSN 1748-0485

It is advisable to refer to the publisher's version if you intend to cite from the work. http://dx.doi.org/10.1177/1748048516640212

For more information about UCLan's research in this area go to http://www.uclan.ac.uk/researchgroups/ and search for < name of research Group>.

For information about Research generally at UCLan please go to http://www.uclan.ac.uk/research/

All outputs in CLoK are protected by Intellectual Property Rights law, including Copyright law. Copyright, IPR and Moral Rights for the works on this site are retained by the individual authors and/or other copyright owners. Terms and conditions for use of this material are defined in the policies page.

\section{CLoK}

Central Lancashire online Knowledge www.clok.uclan.ac.uk

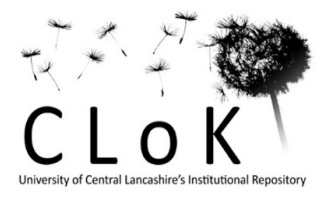




\section{Fragile finance: The revenue models of oppositional news outlets in}

\section{repressive regimes}

\section{Introduction}

Exiled and restricted media struggle for free expression against government oppression. For some of the world's most media-restricted countries, news publishers are considered criminals for maintaining freedom of expression: within the case studies included here journalists have been killed, threatened and imprisoned, sites have been shut down, cyber attacks carried out and offices destroyed. Here, exiled media refers to a media outlet that can no longer function in the country relating to its content, and operates in either self-imposed removal or enforced removal, due to danger. In contrast, information providers in restrictive news environments are in-country news outlets. Both share a focus on providing alternative media discourse, championing alternative viewpoints and often work to expose corruption. Their finances are particularly fragile.

While this study shows diversity among media on factors such as launch date, audience size and level of funding, it highlights a number of commonalities to justify comparability. Firstly, these relate to core values and motivations: most are passionate about journalism with a desire to truth-tell, hold decision makers accountable, and disseminate inaccessible material. They were driven to improve their country by fostering an informed citizenry. The second commonality is in the overall fragility of their existence, due to a lack of economic sustainability. These media are often manned by small teams with very limited resources and face day-to-day challenges in terms of infrastructure and threats of arrest and violence. Their financial operations are restricted and the market classed as flawed because they cannot work as normal business entities due to harassment, 
business pressures and restrictions, and legal complexities. Podesta (2009) identifies 'soft censorship' to include pressure by governments on commercial enterprises to advertise in certain media and not in others. Market distortions materialise for many reasons: the economy may be so weak that local businesses have no incentive, or ability, to advertise; literacy and the purchasing power of citizens are low; oppressive regimes distort advertising by controlling who works with whom; legal and political constraints present obstacles to business development; cultural barriers create audience apathy. They exist despite distortions in both the commercial market and administrative systems, and operate in isolated conditions (CIMA 2007; Nelson 2011; Fojo Media Institute 2013).

\section{Aims}

This article presents analysis generated from a consultation on the funding structures of 19 independent exiled or restricted media outlets. These include media outlets cover the Caucasus, Belarus, Zimbabwe, Zambia, Uzbekistan and Turkmenistan, Sri Lanka, Syria and Iran. The economic aspect of oppositional media is poorly developed as a scholarly research area. This article focuses on gathering empirical evidence of their revenue streams. It does this against the backdrop of revenue diversification: grant funders seek evidence of more revenue streams being used, and a trend for diversified revenues by media in more open markets. In this way, the study evidences the extent to which exiled and restricted media are moving on a trajectory towards a more business-driven environment, and the role diversified revenue streams play in achieving a more robust economic structure. 
A taxonomy of three main revenue categories is discussed. Firstly, grant income (media development aid) and its impact on economic viability. Secondly, earned income (commercial revenues or services), including advertising as a revenue source, sales, affiliate marketing and others including cross-subsidy from for-profit business ventures. Thirdly, private donations (from individuals or through crowdfunding) are discussed including non-monetary exchange, where services can be 'traded' as part of an alternative value system. The article also examines significant internal and external barriers that thwart business development. By exploring the interplay of public and private funding with commercial revenues, the article suggests areas worthy of further exploration capable of promoting longer-term economic resilience.

\section{International development aid to news media}

Media assistance as an element of democracy and development has emerged progressively since the United Nations Conference on Freedom of Information in 1948, broadly settling into two often overlapping perspectives: media for development (communicating a message) and media development (supporting media per se). Media are recognised as important vehicles to address state fragility and wider conflict resolution as they can create the conditions for political or economic change. More recently, supporting independent media has gained prominence within the UN good governance agenda (Wilson et al 2007) for its potential to mitigate against misrule. According to US pro-democracy think-tank Freedom House, global press freedom fell to its lowest level in more than a decade paradoxically against a backdrop of diverse news sources and platforms (Freedom House 2014). 
Within the environment of international media aid flow, unpicking who gets what from whom and why is complex for a number of reasons. Firstly, assessing a country's press freedom is problematic. Two leading frameworks, the Freedom House Free Press Survey and the Press Freedom Index from Reporters Without Borders, use different methodologies. The toolkit approach to assessing media development (Banda and Berger 2014) goes some way to being more flexible and responsive. Secondly, press freedom itself is an uncertain concept, understood differently across democracies and authoritarian regimes (HoltzBacha 2004). Even of the Western democracies seen to enjoy press freedom, the legal, regulatory and conceptual environments differ considerably. Thirdly, the wider politics of international development aid is determined at least partly by the commercial and political self-interests of particular donor countries, by geopolitical and strategic considerations that far outweigh developmental motives (Alesina and Dollar 2000) or by trade interests (Berthélemy 2006) that result in links between foreign policy interests. The British and US governments expend a disproportionate amount to Iraq and Afghanistan while others adopt a 'flavour of the month' syndrome (Nelson 2011a) sometimes at cross-purposes with military media priorities (Cary 2010). Focusing on advocacy non-governmental organisations (NGO)s in Asia, Parks (2008) notes how "donor priorities are constantly shifting". The British government eliminated all foreign aid to 16 countries, many in Africa, as part of an effort to 'rebalance' its international development budget (Watt and Walsh 2011).

It is equally difficult to establish clear estimates of the amount of money dedicated to media support as it is often part of generalised democracy and governance (Deane 2013), from multiple portfolios, and actions often result in a lack of close donor coordination (Fuchs et al 2015). Estimates suggest that \$441 
million of Official Development Assistance was spent on media support (of which 45\% was spent on media development and 19\% on media infrastructure) in 2012 from member governments of the Organisation for Economic Cooperation and Development (OECD). The biggest media assistance providers were Germany, the United States, Japan, Sweden and the EU institutions. There is much variation in levels of support, country-to-country. The largest beneficiary region was Asia, closely followed by Africa, according to analysis by Cauhape-Cazaux and Kalathil (2015). They note that many governments shy away from any kind of support of media because it is seen as too sensitive.

However media development assistance is happening across an everwidening range of aid agencies, international organisations, private foundations, media-based and, most recently, new technology and internet freedom philanthropies. It is impossible to conclusively measure the amount of funding available due to the blurring of boundaries across these actors. However Nelson (2009; 2011a) makes inroads into documenting US private foundation experiences. For example, one of the leading private funders in freedom of expression is Open Society Foundations. Out of $\$ 40-50$ million on media development, a share of $\$ 10$ million is spent on freedom of expression. Where funds are allocated, they have begun to target areas of broad need: tackling a deficiency of basic business skills, a lack of market data and increasingly audience research (Foster 2014). Donors adopt an integrated model of support to encompass editorial quality, infrastructure and financial sustainability. Some evidence of economic sustainability is increasingly required as part of grant eligibility criteria.

With media moving rapidly into the digital space and the evolution of technologies, the question of how to sustain media will grow in importance. 
According to Lara Arogundade, director of media NGO International Press

Centre: 'Media centres will have to creatively think of rendering services for which they could receive payment so as to be able to meet aspects of their operational costs' (CIMA 2007). Equally, members of IFEX, the global freedom of expression network, reported it had become 'strikingly more difficult to obtain funding for their work' (Becker and Vlad 2009). Long-standing information providers such as Short Wave Radio Zimbabwe and Uznews.net Uzbekistan, for example, closed in 2014 due to lack of funding. These changes put revenue, and diversification of revenue streams, as a more pressing consideration on those media working to maintain the free information flow.

\section{Literature review}

From the perspective of media economy, there are two fundamental but not mutually exclusive models with which to frame the media industry: the market and public interest models (Croteau and Hoynes 2001; Tunstall 1991). One might expect scholarship on media systems to inform the relationship between exiled media and their various governments, but most of the literature focuses on the mainstream news organisations in each country (Hallin and Mancini 2004; Hallin and Mancini 2011) or press classifications (Hachten 1999), ignoring small and atypical oppositional media surviving at the edges of the political system and the economy. Exiled media lead a nomadic existence, and fit neatly into the media systems neither of their home countries nor adopted countries (Dobek-Ostrowska et al 2010). As explored by Obijiofor and Hanusch (2011) media systems are more heterogeneous than they are homogeneous, influenced heavily by regional cultural and political experiences, as well as different economic forces. Where media system frameworks fall particularly short is to ignore the operating 
environment of exiled media, often rooted in the specific evolution of media and politics in these countries.

Scholars have focussed more on media development in terms of roles and democracy. For example Hughes and Lawson (2005) discuss the struggle to deepen democracy in Latin America through media diversity, while Waisbord (2007) and Becker (2011) argue that media can raise awareness and affect accountability. Moyo (2009) performs a content and form analysis of three online news services in Zimbabwe to establish the role played by the internet on democracy while Bratic (2006) argues for the potential of digital media to increase democratic participation in conflict situations. Studies suggest betterinformed citizens are more likely to vote, which encourages politicians' responsiveness (Stromberg 2004), and freedom of the media is highly correlated with broader political freedoms (Karlekar and Becker 2014). Although the effect is arguable, reductions in restrictions on journalists can have a positive impact on corruption (Freille et al 2007), and free press can be a control on corruption (Brunetti and Weder 2003; Chowdhury 2004).

What is lacking is better understanding of how the emergence of Gillmor's citizen empowerment (2010) or Castells' (2007) mass self-communication and counter power can be financially sustained in restrictive environments. Without an effective funding structure, the fundamental capacity for 'social movements and rebellious individuals to build their autonomy and to confront the institutions of society in their own terms and around their own projects' (Castells 2007: 9) as effective actors in deciding power, remains thwarted.

Finding a workable economic solution is an issue in many resource-poor environments. Restricted media are more like non-profit charities, promoting social and public service values than profit-maximising businesses, much like the 
investigative Latin American journalism non-profit sector (Requejo-Aleman and Lugo-Ocando 2014). In digital inclusion projects in India, South Africa and Brazil (Madon et al 2009) piecemeal revenue successes were managed around donations, or partnerships with NGOs, but otherwise long-term indigenous revenue streams were difficult to find. Of most relevance are the scholars who focus on the economic barriers to operations. Parsons et al (2008) map the barriers to media development including economic impoverishment, lack of stable monetary systems, poverty, media consolidation, and the cost of starting out, but stop short of gathering any empirical evidence. Who owns a media outlet and thus controls its sources of capital and revenue are relevant here (Foster 2012).

By focusing on revenue generation this article adds to broader scholarship on how a media does business (Osterwalder et al 2005), the totality of value creation (Afuah and Tucci 2003; Timmers 1998) and market competition (Ethiraj et al 2000; Mayo and Brown 1999). A business model can be evaluated by its financial sustainability equally important for organisations that are cause driven as for those who are profit driven, because they still need income to cover their costs and continue towards their objectives. This article uses a model by Byrne (2010) as a starting point. It describes the actual position of media businesses in emerging and developing markets compared with a desired market-driven position and suggests economic 'robustness' is increasingly facilitated by diversifying revenues (see for example Downie and Schudson 2009, Kaye and Quinn 2010; Grueskin et al 2011; Rosenstiel and Jurkowitz 2012). Beyond bundling hard news with more advert-friendly soft news, modern digital technologies have resulted in revenue diversification and any innovation being grabbed 'with all the enthusiasm previously reserved for lifebelts on the Titanic' (Franklin 2014). In the context of more open markets, Picard (2014) goes on to 
identify optimism in trends for news providers to be less dependent on one form of funding and towards experimentation, be that with mixes of paywalls (Myllylahti 2013; Pickard and Williams 2013) or the commerce potential of mobile news (Nel and Westlund 2012). In Basque and Catalan minority-language media, Zabaleta et al (2014:515) suggest that standard revenue sources can be complemented by a new paying membership or tiered contribution income stream aimed at reinforcing "commitment to and empathy with the media project". Similarly in the digital creative industries, Li (2015) finds that 'portfolio models' are made feasible by digital technologies where each new revenue stream is often financially modest but the combined revenues from different income streams can generate profits. This article gathers empirical data to map the extent to which complementary revenues streams or a portfolio model have been adopted by oppositional media.

Of particular conceptual relevance is the Submojour study (Sirkunnen and Cook 2012) that focuses on the revenue models of 69 media startups in ten freemarket countries. Its exploration of how media are moving towards a more diverse business model combining multiple revenue streams has influenced the research here. It also finds how media are increasingly dividing up their operations around which revenues can be mobilised, both in a storytelling(multiple products and content) and service-orientated model (such as consultancy, training or technology). This can be broadly set against the long tail of media business (Anderson 2006) where digital technologies open up niche media with corresponding opportunities for revenue (Briggs 2012; Bruno and Nielsen 2012). However even in free markets the economic sustainability of niche-based journalism is a struggle due to significant influences of mainstream 
media, markets setting the conditions for using technology and a wide compendium of market forces thwarting revenues (Cook and Sirkunnen 2013).

In contrast, this research hypothesizes that diversified revenues will not return sustainability in the more complex operational setting of restrictive news environments. The term sustainability is understood here economically, referring to a capacity to be viable against the media's objectives in the medium to long term. It does not presume growth or profit, and echoes Elliott (2012:58) who states the need for sustainability to be 'spatially and locally defined'. It takes as a starting point Craig LaMay's definition as 'financial sustainability with a publicservice editorial mission' (CIMA 2007) maintaining both a mission good and a revenue good. A democratic or developmental role cannot exist without a viable business model (LaMay 2006) raising two, sometimes competing, objectives: providing information as a public service and operating a sustainable business. Servaes et al (2012) have produced a helpful framework of sustainability indicators that state 'each society and community must delineate its own strategy to sustainable development starting with the resources and capitals available (not only physical, financial and environmental but also human, social and institutional)'. For many scholars, sustainability relates to development around three pillars: economic, environmental and social (WCED 1987; UNCED 1992). Yet it has become a buzzword with vague meaning (Hull 2008). Two current definitions do not go far enough: neither the International Research and Exchanges Board's Media Sustainability Index (MSI) indicator as the 'ability of media to play its vital role as the 'fourth estate' nor the Center for International Media Assistance definition as 'the ability of media outlets to operate without outside assistance' as they do not offer precision on economic resilience. 
Where understanding of sustainability for media under threat has been consistently acknowledged is by actors in the sector. Of direct relevance, a consultation by non-profit organisation Fojo Media Institute (2013) looked at the sustainability of 14 independent exile media outlets. It found fledgling evidence of revenues from grant income but a lack of impact from those initiatives on overall budgets. A lack of in-house business skills was a key challenge and doubts as to the likelihood of achieving full sustainability in exile were raised (Ibid 2013: 17). Research has also focused on alternative investment models with access to finance being a critical challenge (Wan-Ifra 2011).

The literature lacks empirical data not only to better understand the economic operational circumstances of such media, but to add parameters on a better definition of sustainability in economic terms. This study addresses that knowledge gap by making the connection between economic sustainability and media development, and the role revenue diversification plays in the trajectory towards a more market-driven 'robustness'. This allows for a better understanding of the economic model of such media in their own terms, while still allowing for comparisons with broad trends in niche media markets in open economies where goods and services are freely exchanged, and forces of supply and demand are largely free from government restrictions, price-setting monopoly, or other authority.

\section{Methods}

Semi-structured interviews (26 open and closed questions) were conducted with representatives of exiled media, or media in restrictive environments, between November and December 2013. The sample of 19 media was selected from NGO donor contacts, the researcher's own networks and snowball sampling (in 
which interviewees identify other possible interviewees: Cohen and Manion, 1985), possibly skewing the sample. More systematic sampling was not possible, as no listing or database exists which may explain a lack of academic empirical data to date. In a new research field such as this, data gathered in this way is still valuable.

The sample offered a range of media (online, radio and print) covering the Caucasus, Belarus, Zimbabwe, Zambia, Uzbekistan, Turkmenistan, Sri Lanka, Syria and Iran. The aim was to offer comparability by detecting significant factors in income-generation and to identify experimentation with revenue streams, rather than represent any one country or media format. The sample offered a range of media in terms of age, size and total 2012 revenues (see Table 1) to maximise the comparability of experiences with revenue generation.

\section{[Insert table one about here]}

Eight further interviews using a second semi-structured questionnaire were held with project managers of grant-making organisations and media business specialists in this field. These were conducted face-to-face, to document trends and reflections on the wider context of sustainability among the exiled media community, and as background information.

Here, media outlet refers to any group or organization producing online content independent from, and alternative to, the state-controlled information stream. The sampled media were often small teams with a production process that drew on a range of expertise: from aggregated content pooled from other providers, freelance journalists in-country and in exile (both registered and nonregistered), social media commentators, community volunteers and full-time professional journalists. Anonymity was agreed to assure lives and livelihoods, yet common factors were drawn out to preserve analytical relevance. Exiled 
editors who choose to live in a more open market area and supply content to the diaspora community were not included. Nor does the research include journalists who may be in exile but who work for large, government-sponsored organizations. Where media outlets do appeal to diaspora communities, there must also have been content disseminated to the home country, in order to be included in this research.

\section{Results and discussion}

A broad comparative taxonomy of revenues used by the media under review is shown in Fig 1, in comparison to revenue streams of media startups online in non-repressed environments. Fourteen of 19 media outlets said they were either quite or very confident they would still be around in five years' time.

\section{[Insert Figure 1 about here]}

\section{Grant income}

Given the operational circumstances, exiled and restricted media depend on heavy grant income in most cases. Grants were a substantial source of revenue, or a way of launching, in all but two cases. Grantees acknowledged the need to diversify their sources of income, an official exit strategy away from grant funding and shorter-term grants being on offer. An Amsterdam-based media covering Iran said: 'You must do a lot to get grants now; you must make time for it and do a lot of work.' This concurred with feedback from donors, who said they had to focus on the 'health and integrity' of grant recipients. One foundation project manager said: 'To make sure the media we are supporting is not constantly on the edge of collapse is at the heart of our operations. We put a big emphasis on accounting and strategic planning... to bring business development to the fore.' 
There was evidence in at least five cases that chasing and diversifying grant income was a core strategic decision and was central to the revenue model. These cases offer some evidence that grants have the unintended effect of distorting the market, potentially dissuading outlets from seeking out sustainability through alternative income. A media covering Iran earning $\$ 50-100,000$ said: 'We made the decision eight months ago that we needed to build on different grant income. We are in better shape now that we have other grant sources and not just one.' One covering Syria with annual income of between $\$ 100-200,000$ described how grant bidding influenced their activities. 'We produce content specifically according to the grants we are taking. We needed to find a way to be sustainable by using different NGOs to fund specific shows.' Another covering Syria with under $\$ 50,000$ annually made grant bidding a core goal in the business development. 'We have specifically looked for funding that have renewal or refunding - and they have background experience in our field. Grants are part of our strategic thinking.' In this way, grant income has become part of exiled media DNA, notably for one in-country Zimbabwean site generating $\$ 100-200,000$ in 2012.

Grant income is the one we have experience in and that feels more efficient than moving into less known spaces. We write a proposal and then shop it around. So the solution is to make the grant model less efficient and the other models easier to contemplate. We have years of experience in donor funding and almost none around the other revenues.

\section{Challenges}


There is a risk that a cycle of grant dependency is created. Only two cases in the sample had no grant income. Taking a neoliberal market perspective Goldman (2012) notes, grants need to 'avoid distorting the very markets we hope to strengthen' by disadvantaging stronger for-profit entities which cannot compete against companies that have received large grant support'. An in-country Zimbabwean media outlet generating more than $\$ 200,000$ said: 'Grants and donations can serve to weaken the operations of a company, as the business gets used to living off well-wishers. Any help would have to be calibrated very carefully so that it doesn't impact negatively on the business in the long term.' Impact investing explores how funds can generate measurable social and environmental impact alongside a financial return (Lewin and Smith 2014). Distinguishing grants as seed funding, rather than a sustainable revenue stream, is pertinent against the new venture capital model of philanthropy, such as the Knight Foundation. Grantees receive start-up money, particularly around technology innovations, but are expected to be self-supporting within a few years. In all, a 'donor ecosystem' (Nelson 2011a) is emerging. Mazzucato (2014) would go further advocating an 'innovation ecosystem' in which media could develop through a vibrant interaction of public and private revenues.

\section{Earned income}

Income generated from content is particularly challenging for oppositional media. Where earned income was generated, this was often in limited amounts and activity was considered a chore or a distraction from core activities. That said, there was evidence of a range of earned income streams, and revenue proposals for the future. This demonstrates fledgling moves to a 'mix and match' approach advocated by Briggs for entrepreneurial journalism (2012: 75). However the 
potential for revenues to offer any real impact towards sustainability for individual sites remains questionable.

\section{Advertising}

The study found broad awareness of advertising as a potential revenue stream, with nine sites using some form of advertising. However there was significant variation in the range of expertise. There was a general lack of understanding around advertising types, and terminology. In-country advertising refers to advertisers who are based within the country where content from the media outlet is focused. Out-of-country advertising is where the advertiser represents a product or service that is available beyond the country where content is focused. The genres of advertising evidenced were: display advertising in print, banner advertising online, Google online advertising programme Adwords, native or advertorial, and the use of an online advertising network.

\section{Advertising networks}

Of the sites using advertising, four used an online advertising network. A further four were in negotiations to start, showing it to be the dominant avenue for revenues. It works by pooling media sites into one global advertising network of standard advertising formats and sizes, creating a potential global reach for advertisers demanding a higher price and greater returns for the publishers. The price of advertising varies, depending on the site, country or audience they want to reach. A partnership deal with UK news publisher The Guardian also allows the sale of advertising on behalf of the network with rates of $\$ 2-\$ 20$ per thousand views. For the media outlet, it generates income from out-of-country advertising that would otherwise be elusive, by attracting larger businesses (for example 
within education and banking). The network works on a revenue share, with media outlets being paid $70 \%$ of revenues generated. A challenge is that lucrative brand-led advertising purchases are most common for in-country markets, where the visitors and advertisers are aware of the publisher's brand. Oppositional media are naturally precluded from such deals. The early success of the ad network shows an outline scope for business partnerships.

\section{Display advertising}

Online banner adverts were chosen as a revenue stream for the sites where audience traffic was sizeable enough to make it viable. Banner adverts were sold to a phone provider on a site covering the Caucasus because 'the region is important for them. It is not because they like us for their business strategy. It is because we are big. They know the audience; they want the quantity.' A Belarusean radio station generated advertising as a small share of revenues despite an advertising manager being employed and radio ad rates ranging from $\$ 31-\$ 63$ a minute, plus online banners from 84 cents to $\$ 1$ per thousand views. Advertisers included media and education institutions, concert agencies, mobile phone operators, car traders and travel companies. One Minsk-based website with 106,000 monthly unique users made $\$ 3-4000$ a month from banner advertising. 'Banner advertising used to be minimal but it is growing [but] we don't want too many as we don't want to irritate the audience.'

\section{Native advertising}

Native advertising or 'advertorial' content was used by a site in Belarus with 2012 revenues of less than $\$ 50,000$ but a low reliance on grants: '[These] are much more fun for us. It is a very good sell for us.' They had experimented with one-off 
advertising projects around special edition content, creating virtual shop windows connecting editorial and local artists. 'It generated a very good income. We are now launching this as a permanent service. We have also done branding and sponsoring of articles around one topic, and we profited a lot.' This site had design and coding expertise in-house. Branding spaces as the background for the main home webpage were developed and sold as sponsored sections. 'It is a hybrid of different models that I have seen from other markets and we have had to rethink it for our [restrictive] market which is more complicated than ever. It is about finding the content you want to write about and then building a section around it which can be monetised.'

\section{Sales}

Two media outlets earned money through the cover-price of print editions. In both cases, this revenue stream represented a sizeable proportion of the earned income (60\% of revenues in one case).

This works for us in a cash-strapped Zimbabwe that is suffering liquidity challenges because it means we are able to manage our cash flows better as street sales result in daily cash receipts to fund operations. If we were dependent on advertising we would suffer as advertisers generally take long, an average of 45 days, to pay their bills.

For three sites, revenues were made from affiliate marketing through services such as Amazon affiliates, where the host site receives a small amount for sales placed as a result of directed traffic. For one selling Iranian books it generated small revenues, such as $\$ 1,130$ in one year. Revenue was made using citizen journalism site Demotix, which pays on a revenue share basis for photography when content is sold on to mainstream media, for a site covering Central Asia. 


\section{Cross-subsidies and partnerships}

In two cases, revenues were generated from an umbrella or sister for-profit company. One combined a charitable status media outlet with a communication consultancy for marginalised communities; the other an advertising agency with a media outlet. This allowed revenues from commercial trading, and grant funding through the charitable arm. One in Belarus started producing a youth magazine then had to move underground and, at relaunch, separated an advertising company and a media outlet. 'The 12 years' experience mixing advertising and media has helped. With the income from the advertising business we can adjust the technical services we offer and be more efficient.' In another case, two media sites covering Iran had reciprocal links, each helping to drive traffic to the other. A Zurich-based site focussing on citizen media in Central Asia has developed a portfolio of partnership projects around publishing stories, shared blogging platforms, teaching and testing for a university.

\section{Challenges}

There were two types of constraints on earned revenue: a conflict between editorial mission and commercial activity; and operational complexities. A site covering the Caucasus said: 'We write about disappearances, tortures, the hardest stories on human rights violation, and advertisers do not want to be associated with that.' Politically repressive governments also put pressure or constraints on companies not to advertise in independent media. Another said their target audience was too disparate, and their broadcast time too short to be of value to advertisers. Sponsorship and selling merchandise are rarely appropriate, particularly for a Turkmenistan media: 'Selling merchandise would 
be ridiculous. People are not going to wear a T-shirt in the country where even the website is locked and you have to use a proxy service to read it.' There was a sense among some that audiences would no longer support media if they were earning revenues. One Syrian radio said: 'We will lose credibility if we earn income. They are listening to us exactly because we are struggling and nonprofit. If they felt we were making money out of it they would lose faith.' Several sites said advertising would detract from the overall appeal of the site, or would irritate the audience. An Uzbekistan media based in Germany said: 'It would make the website look bad; it would trash the editorial and for $\$ 200$ a year it's not feasible.' Some felt that commercial activity was incompatible with their mission. '[Earned revenue] is not part of our business strategy because our roots are editorial.' An out-of-country Turkmenistan site with $\$ 50-100,0002012$ revenues suggested grant funds be held centrally: 'Given the high risks [this] would protect or restore our online platforms, to provide emergency support to our correspondents to organize necessary meetings, to urgently replace equipment.' Several said that asking for any type of payments for the content, either directly or via donations, thwarted efforts to gain reach. The priority was for 'freedom of speech' and for anyone to take the information for free, as long as it gets out there.

There were operational difficulties in earning income, such as persuading advertisers to pay on time. Language was also a challenge, in restricting opportunities between websites, selling content onto mainstream media and also in electronic publishing (in the Persian language Farsi, for example, formats would need to be read from right to left). Human resource issues internally were problematic as teams often numbered fewer than ten, with a strong bias to editorial and human rights backgrounds rather than business. A traditional sales 
role on a commission basis was also deemed 'untenable' as they cannot generate enough to make it worth their while, and wages were often ineligible for grant funding. Small teams, often volunteers, were sometimes unable to produce high-quality journalism and this was in turn deemed to limit earned income, as advertisers do not want to be associated with a poor product. Resourcing also affected development of data processing as an income stream. In the UK, for example, a media data dashboard service, such as Leeds Data Mill, is being developed and sold under licence. 'We have to look at our major core needs and things like monetising data are luxury,' said an editor covering the Caucasus.

\section{Donations}

There was a widespread awareness among the media interviewed that donations (any private financial support) would be a step towards revenue diversification. All but five media had experimented in some way with donations but only seven made any revenues and these were often small or piecemeal.

\section{Crowdfunding}

Crowdfunding works by running a fundraising campaign with target funds raised from relatively small user donations that can have the potential to overcome funding gaps (Wingerden and Ryan 2011). Crowdfunding was successful when focused on a specific project or activity and involved international funding on sites such as Indiegogo (and others like it, such as Kickstarter or Spot.us). This is consistent with the view of Macht and Weatherston (2014), that crowdfunding can help bridge the funding gap between internal (founders, friends, and family) and formal external (media assistance, banks) support. Crowdfunding projects mostly succeed by narrow margins, or else fail by large amounts and reduce the 
importance of traditional geographic constraints (Mollick 2013). One organisation which focuses on bridging a gap between citizen and mainstream media with correspondents in Kenya, India and Sierra Lione used Indiegogo to raise revenues for an in-house Google-to-SMS reporting system. Sixty per cent of target funds were raised, reaching $\$ 16,000$. Another mobilised a large social media campaign to get donations from crowdfunding and private donations around major European cities. This generated $\$ 40,800$ mainly targeting middleclass audiences for the broadcasting of information to Azerbaijan. 'It has to be specific - something passionate that people will get behind. They see it, and read it, and think, I want to be part of that.' In the Caucasus, a crowdfunding initiative was successful generating around $\$ 50,000$ over ten months however it was 'very complicated and it took a lot of time'. The campaign was targeted offline and online, around social media and text messages, to raise awareness of persecution against regime opponents. 'The payments were taken through an equivalent to PayPal, directly into bank accounts and payment stations'.

\section{Microdonations}

One Uzbekhistan outlet had experimented with Flattr, a social micropayment site, where users sign up for an account and transfer money via credit cards or PayPal. This then allows them to financially credit any content they listen to, watch or read by liking it. However it was deemed to have limited success, returning only a handful of small donations. Four respondents said digital infrastructures were an obstacle to generating revenues. Some sites depended on subsidy from individuals involved in the media outlet. Shareholders in one Zimbabwean media provided 60 per cent seed capital that was used to relaunch operations, while another relied on their private funds to support their work. Other 
examples of one-off donations were from private individuals ranging from $\$ 100$ to $\$ 10,000$. One site was given a donation after a speaking engagement.

\section{Non-monetary exchange}

Media outlets benefited from non-monetary exchange, where products or services are swapped instead of currencies. One was successful in encouraging local 'ambassadors' to promote the media activity and attracting unpaid volunteers. The collaborative service site goodfornothing.com, where skills from around the world are offered for free, was used.

\section{Challenges}

Even the most advanced editorially-led initiatives typically generated only a fraction of the overall budget from donations. Apathy and poverty were listed as major obstacles. One Uzbekistan outlet recalled: 'We appealed to the community that it was an SOS message and $\$ 113$ is all we got despite there [being] a huge need for our website. It is a very passive attitude. People are not very politically active and take everything for granted.' A media covering Belarus said the wealthier classes 'need more time to understand they need to pay for media to exist - even the most loyal audiences who download every day are not prepared to pay'. This was compounded with a cultural trend towards normalising piracy and counterfeit goods, which makes 'it very difficult to make people pay for anything online.' An Uzbekistan site said: 'People don't understand that you are part of society. We collected signatures for a petition once and we had only 154 signatures. Engagement in general is very, very low.' A Zimbabwean media earning more than $\$ 200,000$ in 2012 said: 'We have sent letters to universities and associations asking for subscriptions and donations as a gift, or appeals to 
the diaspora asking for gift subscriptions for family back home - they were all a flop.' Other concerns focus on the mission and structure of the media outlet, which opposes donations. 'A lot of people know you get grants and say, why should I pay you?' Another Zimbabwean site said: 'The culture is that if you are a human rights organisation then you are funded and it's not our job to fund you; that information should be free.' This supports recent research around a community journalism project in Kenya, which concluded that residents weren't interested in journalistic work when they were not actively engaged in it (Ekdale 2014).

It was also noted that donations were an unrealistic expectation from incountry and out-of-country audiences who are struggling. A Zimbabwean media said: 'Everyone is poor. They club together and even those in the diaspora work their butt off in the first world to send enough back home, so the last thing on their minds is donating to media.' For Syrians, 'they prefer to give to charities and people who work in relief, not media' according to one respondent. Several sites show some genre of 'donate' appeal on the website. This was universally unsuccessful as an income stream, generating very small revenues. A Zimbabwean site noted: 'We put it there because it seemed to be what you ought to do but it generated less than $\$ 100$ a year.' More generally, banking was problematic for underground organisations. One site covering Sri Lanka said they had a 'specialist account for people wanting to donate but the government has tried to locate us before.' The outlet described how they could not use PayPal because it required specific bank details, which deterred some for fear of persecution (monies had to be transferred to distant relatives in other countries and via third parties so as to remain anonymous). A Zimbabwean site said: 'We would have to move into mobile payment more seriously, for example using 
EcoCash (a Zimbabwean mobile payment solution). However it is quite onerous to get an account. You need to be selling things as an individual or company.'

\section{Conclusions}

Further research is needed on emerging new revenue streams facilitated by alternative technology developments. Further exploration of collaboration in multiple forms (networks, sharing, content platforms) and the potential emergence of an innovation ecosystem in the wider context of value creation (Adner \& Kapoor 2010) would be highly relevant. Rather than merely examining the structure of ties among actors in a network such a focus could offer a perspective on how partnerships might form and in what ways they could generate economic values in order to strengthen financial resilience. This new area of research requires a synthesis of approaches to business, revenue and restricted media.

Across media in exile and in restrictive news environments, there is a persistent reliance on grant funding. For some this has become part of the revenue model DNA and a core strategy. There is evidence of experimentation with a range of revenue streams, such as selling content, advertising, and affiliate schemes as well as appeals for donations or editorial projects funded through crowdfunding. Certainly the knowledge and need to try a variety of revenue streams is widely known. There was some evidence here of the 'bricolage' method (Senyard et al 2014), by which resource-constrained firms make do by applying combinations of resources. It is also possible to see that business structuring and combining commercial or for-profit expertise with non-profit media can return a more robust economic structure. 
The lack of revenue being generated by these initiatives however exposes the difficulty in achieving a 'portfolio model'. Respondents spoke of exploring income from non-information services, moving into journalism training, or developing other services around data, yet these had not begun. There was an overall lack of understanding of the varied perspectives on sustainability, and to reconcile the potential for commercial activities while still being a non-profit public-interest model. There was much confusion about the level of perceived donor knowledge of challenges 'on the ground'. Further research should include longitudinal evaluation and monitoring, to assess sustainability more fully (Servaes et al 2012).

By the definition of sustainability used here, many media are indeed solvent in the medium- to long-term. They are less successful in terms of a funding structure that is more diverse and robust, becoming more self-sufficient and less reliant on grant funding. Media must tailor their offerings and revenue generation capacity to specific economic, political and cultural conditions if they are to adopt the more robust business ideals set out by Byrne (2010). The majority of media outlets were confident about the future and were positive about viability but were less clear how this would be achieved.

The clearest progress towards a sustainable revenue stream was through an advertising network. This works by pooling many media sites together into one global advertising network of standard advertising formats and sizes, thus creating a potential global audience reach for advertisers. It is evidence of the potential for a partnership approach to be used by exiled media outlets: revenues may be as likely to emerge from pooling resources and content as they are around discrete media outlets. There was also interest in coordinated approaches to better facilitate anonymous donations and online or mobile payments, which 
would otherwise be too expensive or technically challenging to set up if taken on at the individual media level. Thus, while radical shifts in journalism through technology and social media are affecting the financing of some media, this does not seem to be the case for oppositional news outlets in exile or repressive regimes. The development of new revenue models or adjustments to revenue strategies remains piecemeal.

\section{Acknowledgements}

Thanks to Dr Andrew Hobbs and two anonymous reviewers for comments on earlier drafts. The findings are based on further analysis of data collected as part of grant-commissioned research.

\section{References}

Adner R and Kapoor R (2010) Value creation in innovation ecosystems: how the structure of technological interdependence affects firm performance in new technology generations. Strategic Management Journal 31 (3): 306-333.

Afuah A and Tucci C, (2003) Internet Business Models and Strategies. Boston: McGraw-Hill

Alesina A and Dollar D (2000) Who Gives Foreign Aid to Whom and Why? Journal of Economic Growth (5) 1: 33-63.

Anderson C (2006) The Long Tail: How endless choice is creating unlimited demand. US: Random House Business Books.

Banda F and Berger G (2014) Assessing your media landscape available instruments their role and limitations. In: How to assess your media landscape: a toolkit approach. Global Forum for Media Development. Available at http://www.fesmedia- 
asia.org/fileadmin/user upload/ANMB/GFMD-Media assessment tool 2-

$\underline{09 . p d f}$

Becker J (2011) Coverage of the Tibet Crisis (March 2008) and the Olympic

Games in China (August 2008) in the German-language mass media. International Communication Gazette 73: 495-506.

Becker L and Vlad T (2009) Funding for Freedom of Expression Organizations Report of a Survey of IFEX Members. James M. Cox Jr. Center for International Mass Communication Training and Research http://www.ifex.org/international/2009/07/08/cox center funding.pdf

Berthelemy JC (2006) Aid allocation: competing donors' behaviours. Swedish Economic Policy Review 13: 75-109

Bratic V (2006) Media effects during violent conflict: evaluating media contributions to peace building. Conflict and Communication Online 5

Briggs M (2012) Entrepreneurial Journalism: How To Build What's Next For News. Los Angeles: Sage.

Brunetti A and Weder B (2003) A free press is bad news for corruption. Journal of Public Economics 87 (7): 1801-1824.

Bruno N and Nielsen RK (2012) Survival is Success: Journalistic Online StartUps in Western Europe. Oxford: Reuters Institute for the Study of Journalism. Byrne E (2010) Media development market model - forces and influences. Presentation prepared for the launch of the EU funded media assistance programme to Georgia. Tbilisi

Cary P (2010) The Pentagon Information Operations and International Media Development Center for International Media Assistance Available at http://www.voltairenet.org/IMG/pdf/The_Pentagon_International_Media_Deve lopment.pdf 
Castells M (2007) Communication, Power and Counter-power in the Network Society International Journal of Communication 1: 238-266.

Cauhape-Cazaux EG and Kalathil S (2015) Official Development Assistance for Media: Figures and Findings. Center for International Media Assistance. Available at http://www.oecd.org/dac/governancepeace/publications/documentuploads/CIMA.pdf

Chowdhury SK (2004) Do democracy and press freedom reduce corruption? Evidence from a crosscountry study. ZEF discussion papers on development policy 85. Available at http://www.zef.de/uploads/tx_zefportal/Publications/zef_dp85.pdf

CIMA (2007) Toward Economic Sustainability of the Media in Developing Countries. Working Group Report. Available at http://www.cima.ned.org/resource/toward-economic-sustainability-of-themedia-in-developing-countries/

Cohen L and Manion L (1985) Research Methods in Education. London: Croom Helm.

Cook C and Sirkunnen E (2013) What's in a niche? Exploring the business model of online journalism Journal of Media Business Studies 10(4): 63-82.

Croteau D and Hoynes W (2001) The Business of Media: Corporate Media and the Public Interest. London: Sage.

Deane J (2013) Fragile States: the role of media and communication. Policy Briefing BBC Media Action

Dobek-Ostrowska B, Glowacki M, Jakubowicz K and Sukosd M (2010) Comparative Media Systems: European and Global Perspectives. Hungary: Central European University Press. 
Downie LJ and Schudson M (2009) The Reconstruction of American Journalism. Available at http://www.myinfo.dupont.org/system/documents/1/original/Reconstruction_o f_Journalism.pdf

Ekdale B (2014) I Wish They Knew that We are Doing This for Them. Journalism Practice 8: 181-196.

Elliott J (2012) An Introduction to Sustainable Development, 4th ed. New York: Routledge

Ethiraj I, Singh H and Guler I (2000) The Impact of Internet and Electronic Technologies on Firms and its Implications for Competitive Advantage. The Wharton School

Fojo Media Institute (2013) Independent Media In Exile A Baseline Consultation Fojo Media Institute. Available at http://www.intermedia.org/wpcontent/uploads/2013/06/Fojo_Exile_Media_FINAL_PUBLISHED_REPORT_ 19-06-13.pdf

Foster M (2012) Calling the shots: how ownership structures affect the independence of news media Center for International Media Assistance Available at http://www.cima.ned.org/resource/calling-the-shots-howownership-structures-affect-the-independence-of-news-media-2/

Foster M (2014) Measuring the audience: why it matters to independent news media and how it can contribute to media development Center for International Media Assistance Available at http://www.cima.ned.org/publication/measuring_the_audience_why_it_matt ers_to_independent_news_media_and_how_it_can_contribute_to_media_de velopment/

Franklin B (2014) The Future of Journalism Journalism Practice 8: 469-487. 
Freedom House (2014) Freedom of the Press 2014

https://freedomhouse.org/report/freedom-press/freedom-press2014\#.VdrloehViko Accessed August 2015

Freille S, Haque EM and Kneller R (2007) A contribution to the empirics of press freedom and corruption. European Journal of Political Economy 23 (4): 838862

Fuchs A, Nunnenkamp P and Ohler H (2015) Why Donors of Foreign Aid Do Not Coordinate: The Role of Competition for Export Markets and Political Support The World Economy (38) 2: 255-285

Gillmor D (2010) Mediactive. New York: Dan Gillmor

Goldman P (2012) The Distortion Risk in Impact Investing. Stanford Social Innovation Review. Available at:

http://www.ssireview.org/blog/entry/the_distortion_risk_in_impact_investing

Grueskin B, Seave A and Graves L, (2011) The Story So Far: What We Know About the Business of Digital Journalism. Columbia Journalism Review. Hachten W, (1999) The World News Prism: Changing Media for International Communication. US: Ames lowa State University Press.

Hallin DC and Mancini P, (2004) Comparing Media Systems: Three Models of Media and Politics. London: Cambridge University Press.

Hallin DC and Mancini P, (2011) Comparing Media Systems Beyond the Western World. London: Cambridge University Press.

Holtz-Bacha C (2004) What is 'good' press freedom? The difficulty of measuring freedom of the press worldwide Available at http://www.kowi.wiso.unierlangen.de/publikationen/docs/good_press_freedom.pdf Hughes S and Lawson C (2005) The Barriers to Media Opening in Latin America. Political Communication 22: 9-25. 
Hull Z, (2008) Sustainable development: premises, understanding and prospects. Sustainable Development 16: 73-80.

Karlekar K and Becker LB (2014) By the numbers: tracing the statistical correlation between press freedom and democracy. Center for International Media Assistance. Available at: http://www.cima.ned.org/resource/by-thenumbers-tracing-the-statistical-correlation-between-press-freedom-anddemocracyl

Kaye J and Quinn S, (2010) Funding Journalism in the Digital Age: Business models, strategies, issues and trends. New York: Peter Lang.

LaMay C (2006) Democratization and the Dilemmas of Media Independence. The International Journal of Not-for-Profit Law 8 (4).

Lewin M and Smith B (2014) The Next Great Frontier of Impact Investing.

Stanford Social Innovation Review Available at

http://www.ssireview.org/blog/entry/the_next_great_frontier_of_impact_invest ing

Li F (2015) Digital Technologies and the Changing Business Models in Creative Industries. Presented at the 48th Hawaii International Conference on System Sciences.

Macht SA and Weatherston J (2014) The Benefits of Online Crowdfunding for Fund-Seeking Business Ventures Strategic Change 23: 1-14.

Madon A, Reinhard N and Walsham D (2009) Digital Inclusion Projects in Developing Countries - Processes of Institutionalisation Information. Technology for Development 15(2): 95-107. Mayo M and Brown G, (1999) Building a competitive business model. Ivey Business Journal 63(3): 18 
Mazzucato M (2014) The Economist. Startup myths and obsessions. Available at http://www.economist.com/blogs/schumpeter/2014/02/invitation-marianamazzucato

McKeever D (2014) in International Aid Transparency Initiative Annual Report 2014. Available at http://www.aidtransparency.net/reports/IATI-annual-report2014.pdf

Mollick ER (2013) The Dynamics of Crowdfunding: An Exploratory Study. Social Science Research Network, Rochester, NY.

Moyo L (2009) Repression, Propaganda and Digital Resistance: New Media and Democracy in Zimbabwe. In: Mudhai F, Tettey W, and Banda F, (eds) African Media and the Digital Public Sphere. USA: Palgrave.

Myllylahti M (2013) Newspaper Paywalls—the Hype and the Reality. Digital Journalism 2: 179-194.

Nel F and Westlund O (2012) The 4c's of Mobile News. Journalism Practice 6: 744-753.

Nelson A (2009) Experimentation and Evolution in Private US Funding of Media Development Center for International Media Assistance Available at http://www.cima.ned.org/resource/experimentation-and-evolution-in-privateu-s-funding-of-media-development/

Nelson A (2011) Financially Viable Media in Emerging and Developing Markets. World Association of Newspapers and News Publishers. Available at: http://www.wan-

ifra.org/sites/default/files/field article file/Financial Viability Report WAN$\underline{\text { IFRA.pdf }}$

Nelson A (2011a) Funding Free Expression: Perceptions and Reality in a Changing Landscape. Center for International Media Assistance Available at 
http://www.cima.ned.org/resource/funding-free-expression-perceptions-andreality-in-a-changing-landscape/

Obijiofor L and Hanusch F (2011) Journalism Across Cultures: An Introduction. London: Palgrave

Osterwalder A, Pigneur Y and Tucci CL (2005) Clarifying Business Models: Origins, Present, and Future of the Concept. Communications of the Association for Information Systems 16(1).

Parsons P, Landersberg R and Scott G, (2008) Barriers to Media Development. In: Beer AS de, Merill (eds) Global Journalism: Topical Issues and Media Systems, Boston: Pearson. $5^{\text {th }}$ edition.

Parks T (2008) The Rise and Fall of Donor Funding for Advocacy NGOs: Understanding the Impact Development in Practice 18 (2): 213-222

Picard RG (2014) Twilight or New Dawn of Journalism? Journalism Studies 15: $500-510$.

Pickard V and Williams AT (2013) Salvation Or Folly? Digital Journalism 2: 195213.

Podesta D (2009) Soft censorship: how governments around the globe use money to manipulate the media. Center for International Media Assistance. Available at http://www.cima.ned.org/resource/soft-censorship-howgovernments-around-the-globe-use-money-to-manipulate-the-media/

Requejo-Alemán JL and Lugo-Ocando J (2014) Assessing the Sustainability of Latin American Investigative Non-profit Journalism. Journalism Studies 15: $522-532$.

Rosenstiel T and Jurkowitz M (2012) The Search for a New Business Model: An in-depth look at how newspapers are faring trying to build digital revenue. Pew Research Center. Available at 
http://www.journalism.org/files/legacy/SEARCHFORNEWREVENUEMODEL. pdf

Senyard J, Baker T, Steffens P and Davidsson P (2014) Bricolage as a Path to Innovativeness for Resource-Constrained New Firms. Journal of Product Innovation Management 31: 211-230.

Servaes J, Polk E, Shi S, Reilly D and Yakupitijage T (2012) Towards a framework of sustainability indicators for "communication for development and social change" projects. International Communication Gazette 74: 99123.

Sirkunnen E and Cook C (2012) Sustainable Business Models in Journalism:

Chasing Sustainability on the Net. COMET. Available at:

http://www.submojour.net/archives/989/table-of-contents/

Stromberg D (2004) Radio's impact on public spending. The Quarterly Journal of Economics (1) 119: 189-221

Timmers P (1998) Business models for electronic markets. Electronic Commerce $1-6$.

Tunstall J (1991) A Media Industry Perspective. In: Anderson, J (eds)

Communication Yearbook 14 162-186. Newbury Park: Sage.

UNCED (1992) United Nations Conference on Environment and Development in Rio de Janeiro, Brazil. Available at:

https://sustainabledevelopment.un.org/content/documents/Agenda21.pdf

Waisbord S (2007) Democratic Journalism and "Statelessness". Political Communication 24:115-129.

Wan-Ifra (2011) Addressing the Capitalization Gap for Independent News Media Mobilizing funding for Independent News Media. Available at http://www.wan- 
ifra.org/reports/2011/04/01/addressing-the-capitalization-gap-for-

independent-news-media

Watt N and Walsh D (2007) Britain to cut aid to world's poorest countries The Guardian Avaialble at http://www.theguardian.com/globaldevelopment/2011/mar/01/uk-cuts-aid-poorest-countries

WCED (1987) Our Common Future. World Commission on Environment and Development. Oxford: Oxford University Press.

Wilson M, Warnock K and Schoemaker E (2007) At the heart of change: the role of communication in sustainable development. Panos London. Available at: http://panos.org.uk/wpcontent/files/2011/01/heart_of_change_weby2wvJO.pdf

Wingerden RV and Ryan J (2011) Fighting for Funds: An Exploratory Study into the Field of Crowdfunding. Degree project. Available at: http://lup.lub.lu.se/luur/download?func=downloadFile\&recordOId=1982630\&fi leOld=2436193

Zabaleta I, Ferré-Pavia C, Gutierrez A, Fernandez I and Xamardo N (2014) Future Business Innovation in Minority Language Media. Journalism Practice 8: 508-518. 